\title{
PENGETAHUAN DAN PERSEPSI GURU BAHASA INDONESIA SMK SE-KABUPATEN BANYUMAS TENTANG EVALUASI PEMBELAJARAN KETERAMPILAN BERBAHASA PRODUKTIF DALAM KURIKULUM 2013
}

\author{
Fane Trisna Fitriana ${ }^{1}$, Furqanul Aziez ${ }^{2}$ \\ ${ }^{1,2}$ Program Studi Magister Pendidikan Bahasa dan Sastra Indonesia, \\ Univeristas Muhammadiyah Purwokerto
}

Email: fanefitria@gmail.com, f.aziez2010@gmail.com

\begin{abstract}
Abstrak
Penelitian ini bertujuan untuk mendeskripsikan pengetahuan dan persepsi guru bahasa Indonesia SMK Se-Kabupaten Banyumas tentang evaluasi pembelajatan keterampilan berbahasa produktif dalam Kurikulum 2013. Jenis penelitian yang digunakan yaitu deskriptif kuantitatif dengan menggunakan angket atau kuesioner dan tes sebagai instrumen penelitiannya. Pengambilan sampel pada penelitian ini menggunakan purpose sampling (sampel bertujuan). Penentuan sampel ditentukan sesuai dengan kebutuhan peneliti, dikarenakan jumlah populasi pada penelitian ini adalah guru bahasa Indonesia SMK sekabupaten Banyumas yang berjumlah 136 orang dengan sampel berjumlah 20 orang. Pengumpulan data dilaksanakan secara online dengan memanfaatkan aplikasi google forms. Validitas instrumen yang digunakan adalah validitas isi. Teknik analisis data yang digunakan adalah statistik deskriptif. Bedasarkan hasil penelitian, ditemukan bahwa: 1) 79,2\% guru dapat memahami dan melaksanakan evaluasi penilaian keterampilan berbicara, 2) $86,3 \%$ guru dapat memehami dan melaksanakan evaluasi penilaian keterampilan menulis, 3) berkenaan dengan temuan pertama dan kedua, ternyata tidak sebanding dengan perolehan persentase kesulitan yang dialami guru yaitu $10 \%$ guru 'sangat setuju', 65\% guru 'setuju', dan 5\% guru 'tidak setuju' bahwa penilaian afektif sulit untuk dilaksanakan, 4) 5\% guru 'sangat setuju', 40\% guru 'setuju', dan 50\% guru 'tidak setuju' bahwa penilaian kognitif sulit untuk dilaksanakan, 5) 5\% guru 'sangat setuju', 30\% guru 'setuju', dan 45\% guru 'tidak setuju' bahwa penilaian psikomotor sulit untuk dilaksanakan. 6) walaupun guru mengalami hambatan dalam pelaksanaan penilaian afektif (sikap), hampir semua guru sebenarnya sudah mengetahui dan memahami ketiga aspek penilaian tersebut. Hanya saja pada penilaian afektif, guru masih mengalami sedikit kesulitan untuk melaksanakannya. Berkenaan dengan hal tersebut, peneliti berharap kepada guru bahasa Indonesia SMK di wilayah kabupaten Banyumas untuk mengkaji kembali evaluasi pembelajaran keterampilan berbahasa produktif terutama pada penilaian afektif (sikap). Selain itu untuk meminimalisasi hambatan tersebut, perlu diadakan tindak lanjut yang dapat berupa pelatihan atau workshop mengenai penyelenggaraan ketiga aspek penilaian dalam evaluasi pembelajaran keterampilan berbahasa produktif.
\end{abstract}

Kata kunci: pengetahuan, persepsi guru, evaluasi pembelajaran, dan keterampilan berbahasa

\footnotetext{
Abstract

The study aimed to describe the understanding and perception of indonesian teachers of vocational school in banyumas district toward the evaluation of productive language skills in the 2013 curriculum. The research is descriptive quantitative which used questionnaire and tests as research instruments. Sampling in this study used purpose sampling (sample
} 
aims). Mention the number of sample were determined according to the needs of researchers, because the number of population in this study were teachers Indonesian SMK in Banyumas district, amounting to 136 people and spreading in Banyumas. Data collection was carried out through online by used google forms application. The validity of the instrument used was content validity. The technic of the analysis data used statistic descriptive. according to the result of the research showed that: 1) $79.2 \%$ teachers can understand and carry out the evaluation of speaking skills assessment; 2) 86.3\% of teachers can understand and carry out the evaluation of writing skills assessment; 3) regard to the first and second findings, it was not proportional to the acquisition of the percentage of difficulties experienced by teachers $10 \%$ of teachers 'strongly agree', $65 \%$ of teachers 'agree' and 5\% of teachers 'disagree' that affective assessments are difficult to carry out; 4) 5\% teachers 'strongly agree', $40 \%$ of teachers 'agree' and 50\% of teachers 'disagree' that cognitive assessments are difficult to carry out; 5) 5\% of teachers 'strongly agree', $30 \%$ of teachers 'agree' and 45\% of teachers 'disagree' that psychomotor assessments are difficult to carry out; 6) although teachers obstacles in implementing affective (attitude) assessments, almost all them actually already know and understand these three aspects of assessment. It's just that in affective assessment, teachers still have a little difficulty implementing it. In this regard, the researcher hopes that Indonesian language teachers in SMK in the Banyumas district to review the evaluation of learning productive language skills, especially on affective (attitude) assessments. In addition, there should be training or workshop on the implementation of three aspects of assessment in the evaluation of language learning productive skills.

Keywords: perception, understanding, learning evaluation, and language skills

\section{PENDAHULUAN}

Penyelenggaraan pembelajaran bahasa Indonesia memerlukan kompetensi guru diantaranya yaitu kompetensi pedagogik, kompetensi kepribadian, kompetensi sosial, dan kompetensi profesional. Berkenaan dengan hal tersebut, kompetensi profesional merupakan salah satu kemampuan yang harus dimiliki guru dalam merencanakan dan melaksanakan proses pembelajaran. Guru seharusnya menguasai evaluasi pembelajaran maupun penilaian hasil belajar, agar dapat diketahui sejauh mana keberhasilan pembelajaran, kemampuan siswa, dan untuk menentukan langkahlangkah yang perlu dilakukan pada pembelajaran selanjutnya. Penilaian hasil belajar dapat dijadikan sebagai feed back (umpan balik) dalam memperbaiki kegiatan pembelajaran berikutnya. Oleh karena itu, tidak mengherankan jika semua mahasiswa Fakultas Keguruan dan
Ilmu Pendidikan (FKIP) juga harus dibekali pengetahuan tentang evaluasi pembelajaran.

Evaluasi pembelajaran dalam hal ini ialah penilaian hasil belajar. Penilaian hasil belajar yang sering disajikan guru adalah ulangan harian. Ulangan harian termasuk ke dalam penilaian formatif, seperti yang dikemukakan oleh Arikunto (2010: 43) bahwa tes formatif bisa disamakan dengan ulangan harian sedangkan tes sumatif dapat disamakan dengan ulangan umum. Ulangan harian merupakan jenis penilaian hasil belajar yang disajikan oleh guru pada setiap akhir program pembelajaran sesuai dengan kedalaman materi. Pelaksanaan penilaian ulangan harian tidak serta-merta dilakukan secara mendadak atau tanpa perencanaan. Ulangan harian sebelumnya sudah direncanakan terlebih dahulu oleh guru untuk mendapatkan data hasil belajar siswa yang maksimal dan akurat. 
Namun, pada kenyataannya guru masih mengalami kesulitan dalam mengadakan ula $n$ nan harian yang berkenaan dengan kete-rampilan menulis. Kebanyakan guru masih merasa kesulitan dalam membuat intrumen penilaian keterampilan menulis. Hal tersebut dibuktikan dengan adanya penelitian yang peneliti adakan pada tahun 2018, penelitian tersebut berjudul Pelaksanaan Penilaian Ulangan Harian Hasil Belajar Bahasa Indonesia Oleh Guru-guru SMA Se-Purwokerto Tahun Pelajaran 20172018. Dalam penelitian tersebut, peneliti membahas mengenai implementasi atau pelaksanaan ulangan harian bahasa Indonesia yang biasa diadakan oleh guruguru SMA Se-Purwokerto. Dalam pelaksanaannya, diketahui bahwa masih banyak guru yang kesulitan dalam menyusun instrumen penilaian keterampilan menulis yang efektif.

$$
\text { Padahal seorang guru, }
$$

seharusnya tidak hanya menyusun perencanaan dan melak-sanakan kegiatan belajar saja tetapi juga perlu mengadakan evaluasi pembelajaran. Adanya evaluasi pembelajaran bertujuan untuk mempetimbangkan keputusan dan kebijakan dalam kegiatan belajar yang sudah serta akan dilakukan selanjutnya. Dalam evaluasi pembelajaran, semua kegiatan belajar diharapkan mendapatkan hasil yang lebih baik dan memuaskan dari hasil yang diperoleh pada saat kegiatan belajar sebelumnya. Tidak hanya itu, evaluasi juga seharusnya dilakukan secara berkesinambungan atau berkala dengan melakukan pengukuran dan pengambilan keputusan berdasarkan pengukuran yang sudah dilakukan. Kemudian, hasil pengukuran tersebut juga dapat dijadikan sebagai informasi untuk memperbaiki atau memper $\neg$ tahankan suatu pendekatan, metode, strategi, serta media yang digunakan.

Tidak hanya itu, persepsi dan penge-tahuan guru terhadap evaluasi pembelajaran juga perlu diperhatikan. Hal tersebut berkaitan erat dengan pemahaman dan pemaknaan guru bahasa Indonesia terhadap evaluasi pembelajaran itu sendiri. Dari persepsi tersebut, guru bahasa Indonesia dapat melakukan evaluasi pem $\neg$ belajaran sesuai dengan pemahaman dan pemaknaannya. Namun, tak sedikit pula guru bahasa Indonesia yang memiliki perbedaan persepsi mengenai evaluasi pembelajaran. Adanya perbedaan persepsi mengenai evaluasi pembelajaran bahasa Indonesia akan membawa hasil yang berbeda pula antara yang satu dengan yang lainnya.

Berkenaan dengan fenomena tersebut, dalam penelitian sebelumnya juga diketahui bahwa sebagian guru acap kali masih merasa kebingungan dalam menyusun butir soal bahasa Indonesia Kurikulum 2013. Tidak hanya itu, Kemendikbud juga sempat melansir perma-salahan Kurikulum 2013, pada awal pene-rapannya tahun 2014 lalu. Seperti yang dijelaskan oleh Kurniasih (2016: 5) mengenai beberapa permasalahan Kurikulum 2013, sebagai berikut.

1. Tidak ada kajian terhadap penerapan Kurikulum 2006 yang berujung pada kesimpulan urgensi perpindahan kepada Kurikulum 2013.

2. Tidak ada evaluasi menyeluruh terhadap uji coba penerapan Kurikulum 2013 setelah setahun penerapan di sekolah-sekolah yang ditunjuk.

3. Kurikulum sudah diterapkan di seluruh sekolah di bulan juli 2014, sementara intruksi untuk melakukan evaluasi baru dibuat 14 oktober 2014, yaitu enam hari sebelum pelantikan presiden baru (Peraturan Menteri no 159).

4. Penyeragaman tema di seluruh kelas, sampai metode, isi pembelajaran dan buku yang bersifat wajib sehingga terindikasi pembe $\neg$ lajaran dan buku yang bersifat wajib sehingga 
terindikasi bertentangan dengan UU Sisdiknas.

5. Penyusunan konten KI (Kompetensi Inti) dan KD (Kompetensi Dasar) yang tidak seksama sehingga menyebabkan ketidakselarasan.

6. Kompetensi Spiritual dan Sikap tertalu dipaksanakan sehingga mengganggu sub-stansi keilmuan dan menimbulkan kebingungan dan beban administrasi berlebihan bagi para guru.

7. Metode penilaian sangat kompleks dan menyita waktu sehingga mengganggu substansi keilmuan dan menimbulkan kebingungan dan beban administratif berlebihan bagi para guru.

8. Metode penilaian sangat kompleks dan menyita waktu sehingga membingungkan guru dan mengalihkan fokus dari memberi perhatian sepenuhnya pada siswa.

9. Ketidaksiapan guru menerapkan metode pembelajaran pada Kurikulum 2013 yang menyebabkan beban juga tertumpuk pada siswa sehingga menghabiskan waktu siswa di sekolah dan di luar sekolah.

10. Berganti-gantinya regulasi kementerian akibat revisi yang berulang.

Berdasarkan beberapa permasalahan tersebut, pada saat itu kenyataannya Kurikulum 2013 yang diterapkan di seluruh sekolah belum dievaluasi kesesuaian antara ide, desain, dokumen hingga dampak perubahan kurikulum. Adanya beberapa permasalahan tersebut juga mengakibatkan banyak sekolah yang akhirnya kembali menggunakan Kurikulum KTSP (Kurikulum Tingkat Satuan Pendidikan). Hal tersebut juga didukung dengan adanya himbauan dari Kemendikbud, bahwa bagi sekolah yang belum siap menerapkan Kurikulum 2013, boleh kembali menggunakan KTSP.
Tidak hanya itu, bahkan masih ada juga sekolah yang sampai saat ini masih belum menerapkan Kurikulum 2013 edisi revisi dan tetap menerapkan Kurikulum 2013. Hal tersebut dilatar belakangi dengan kurang adanya kesiapan, pengetahuan, dan pelatihan yang matang bagi guru dalam menyusun perencanaan evaluasi pembelajaran bahasa Indonesia Kurikulum 2013.

Hal tersebut juga merupakan persoalan yang masih menjadi perdebatan diantara beberapa guru bahasa Indonesia pada penelitian sebe-lumnya. Dipihak lain, tes keterampilan berbahasa produktif yang hanya menekankan pada (beberapa) aspek kebahasaan tertentu yang mendekati atau bahkan bersifat diskret (berbeda), juga tidak dapat dibenarkan karena kurang bermakna. Pada keterampilan berbicara mem $\neg$ butuhkan adanya pemahaman minimal dari pembicara dalam membentuk sebuah kalimat. Maka dari itu, proses pembelajaran pada keterampilan berbicara akan menjadi mudah jika siswa dapat terlibat aktif dalam kegiatan berkomunikasi. Evaluasi atau penilaian kete $\neg$ rampilan berbicara hendaknya dilakukan secara berbeda pada setiap jenjangnya.

$\begin{array}{rrr}\text { Sedikit } & \begin{array}{r}\text { berbeda } \\ \text { berbicara, }\end{array} \\ \text { keterampilan } & \text { pada }\end{array}$ keterampilan menulis juga diperlukan pula tes yang baik agar dapat memperlihatkan sejauh mana keterampilan tersebut sudah dikuasai siswa. Selain itu, masalah yang muncul dalam penilaian pun harus dipertimbangkan dengan baik untuk meminimalisir kadar subjektivitas pada saat melakukan penilaian. Berkenaan dengan bebe $\neg$ rapa fenomena-fenomena tersebut, maka peneliti menyusun penelitian berjudul "Pengetahuan dan Persepsi Guru Bahasa Indonesia SMK SeKabupaten Banyumas Tentang Evaluasi Pem $\neg$ belajaran pada Keterampilan Berbahasa Prod $\neg$ uktif dalam Kurikulum 2013". 
Sebagaimana diketahui, pengetahuan merupa-kan hasil "tahu" dan ini terjadi setelah orang mengadakan penginderaan terhadap suatu objek tertentu (Wawan, 2011: 11). Penginderaan terhadap objek terjadi melalui panca indera seperti penglihatan, pendengaran, penciuman rasa dan raba. Menurut Kamus Besar Bahasa Indonesia (KBBI) pengetahuan adalah segala sesuatu yang diketahui berkenaan dengan hal (mata pelajaran). Pada proses pembelajaran, pengetahuan dapat dipengaruhi oleh beberapa faktor dari dalam (internal) seperti motivasi dan faktor dari luar (eksternal) seperti sarana informasi yang dise $\neg$ diakan serta keadaan sosial budaya lingkungan sekitar.

Sedikit berbeda dengan KBBI, dalam Wikipedia bahasa Indonesia ensiklopedi online menye $\neg$ butkan bahwa pengetahuan adalah informasi atau maklumat yang diketahui atau didasari oleh seseorang. Pengetahuan akan muncul ketika seseorang menggunakan pikirannya untuk mengenali benda atau kejadian tertentu yang belum pernah dilihat atau dirasakan sebelumnya. Misalnya ketika seseorang mencicipi masakan yang belum pernah dicoba atau yang baru dikenalnya, maka ia akan mendapatkan pengetahuan mengenai bentuk atau rupa, rasa, dan aroma masakan tersebut. Berkenaan dengan beberpa penjelasan tersebut, dapat diketahui bahwa pengetahuan merupakan hasil dari proses mencari tahu, dari yang tadinya tidak tahu menjadi tahu, dari yang tidak dapat menjadi dapat.

Proses mencari tahu mencakup berbagai metode dan konsep-konsep baik melalui proses pendidikan maupun melalui pengalaman. Ada 6 tingkat pengetahuan menurut Notoadmodjo (dalam Wawan, 2011: 12-14) yakni:

1. Tahu (Know), diartikan sebagai mengingat suatu materi yang telah dipelajari sebelumnya.
2. Memahami (Comprehention), artinya seba-gai suatu kemampuan untuk menjelaskan secara benar tentang objek yang diketahui dan dimana dapat menginterpretasikan secara benar.

3. Aplikasi (Application), diartikan sebagai kemampuan untuk menggunakan materi yang telah dipelajari pada situasi ataupun kondisi riil (sebenarnya).

4. Analisis (Analysis) adalah suatu kemapuan untuk menyatakan materi atau suatu objek kedalam komponenkomponen tetapi masih di dalam struktur organisasi tersebut dan masih ada kaitannya satu sama lain.

5. Sintesis (Syntesis) yang dimaksud menun-jukkan pada suatu kemampuan untuk melaksanakan atau menghubungkan bagian-bagian di dalam suatu keseluruhan yang baru.

Menurut Jumiyati (2017: 17-18) pada umumnya pengetahuan dibagi menjadi beberapa jenis, diantaranya:

a. Pengetahuan langsung (immediate) adalah pengetahuan yang lahir dalam jiwa tanpa melalui proses penafsiran dan pemikiran.

b. Pengetahuan tak langsung (mediated) adalah hasil dari pengaruh interpretasi dan proses berpikir serta pengalamanpengalaman yang lalu.

c. Pengetahuan indrawi (persepsional) adalah suatu yang dicapai dan diraih melalui indra-indra lahiriyah.

d. Pengetahuan konseptual (conceptual), tidak terpisah dari pengetahuan indrawi, pikiran manusia secara langsung tidak dapat membentuk suatu konsepsi-konsepsi tentang objek-objek dan perkaraperkara eksternal tanpa berhubungan dengan alam eksternal.

e. Pengetahuan partikular (perticular), berkaitan dengan satu individu, 
obejk-objek tertentu atau realitasrealitas khusus.

f. Pengetahuan universal, mencakup individu-individu yang berbeda, sebagai contoh kita membincangkan tentang manusia, dimana meliputi seluruh individu (seperti Muhammad, Ali, Hasan, Husen), ilmuwan yang mencakup segala individunya (ilmuwan fisika, kimia, atom) atau hewan yang meliputi semua indivisunya (seperti gajah, semut, kerbau, kambing, dan lain-lain).

Secara umum ada tiga bekal yang harus dimiliki seorang guru (1) kompetensi yang cukup, (2) kreatifitas, dan (3) sifat ikhlas. Kehadiran guru dalam kegiatan belajar mengajar (KBM) memegang peranan yang penting. Peranan guru sepenuhnya belum dapat digantikan oleh mesin, video, tape recorder maupun media lainnya. Namun, tidak dapat dipungkiri kemajuan teknologi canggih semakin meningkat sehingga sekarang banyak ditemui adanya pembelajatan melalui aplikasi, video, tv, komputer, handphone, dan lain sebagainya. Cooper (dalam Jumiyati, 2017: 23) mengungkapkan ada empat pengetahuan yang perlu dimiliki guru, yakni:

a. Mempunyai pengetahuan tentang belajar dan tingkah laku manusia.

b. Mempunyai pengetahuan dan menguasai bidang studi.

c. Mempunyai sikap yang tepat tentang diri sendiri.

d. Mempunyai kemampuan teknik mengajar.

Pendapat serupa juga dikemukakan oleh Glosser (dalam Jumiyati, 2017: 23) bahwa ada empat hal yang harus dikuasai guru, yaitu (1) mengusai bahan pelajaran,

kemampuan mendiagnosa tingkah laku siswa, (3) kemam-puan melaksanakan proses pembelajaran, dan (4) kemampuan mengukur hasil belajar siswa. berkenaan dengan hal tersebut cara atau teknik guru menerapkan keempat penguasaan tersebut juga perlu diperhatikan sehingga proses pembelajaran dapat berjalan dengan baik. Jika guru memiliki penguasaan tersebut, maka guru dapat menjadi sosok guru yang berkualitas. jika guru berkualitas, maka dapat mencetak siswa yang berkualitas pula. Tidak hanya itu, berikut ini adalah sepuluh dasar kemampuan yang harus dimiliki oleh seorang guru (Jumiyati, 2017: 25):

a. Mengembangkan kepribadian

b. Menguasai landasan pendidikan

c. Mengusai bahan pembelajaran

d. Menyusun program pembelajaran

e. Melaksanakan program pembelajaran

f. fMenilai hasil dan proses belajar mengajar yang telah dilaksanakan

g. Menyelenggarakan program bimbingan

h. Menyelenggarakan administrasi sekolah

i. Berinteraksi dengan teman sejawat dan masyarakat

j. Menyelenggarakan penelitian sederhana untuk keperluan pembelajaran.

Sebagaimana diketahui, keberhasilan pembelajaran dapat diketahui dari hasil belajar siswa yang didapatkan melalui adanya evaluasi pembelajaran atau penilaian proses dan hasil belajar. Evaluasi pembelajaran merupakan kegiatan yang harus ada dalam setiap program pembelajaran. Berkenaan dengan hal tersebut dapat dikatakan bahwa penguasaan guru terhadap evaluasi pembelajaran menjadi hal yang diwajibkan, karena dapat menjadi tolak ukur dalam menilai kemampuan serta melihat keberhasilan proses pembelajaran yang dilaku-kannya. Selain pengetahuan guru terhadap evaluasi pembelajaran, persepsi guru terhadap evaluasi pembelajaran sangat penting diperhatikan. 
$\begin{array}{crr}\text { Persepsi } & \text { merupakan } \\ \text { kecenderungan } & \text { seseorang } & \text { terhadap }\end{array}$ sesuatu dalam ranah relatif, artinya persepsi individu terhadap sesuatu akan berbeda-beda berdasarkan persepsi dari masing-masing orang (Nugraha, 2015: 3). Persepsi dapat terbentuk dari adanya pengetahuan dengan proses hubungan melihat, mendengar, menyen-tuh, merasakan, dan menerima suatu hal kemudian seseorang menyeleksi, mengorga-nisasi, dan menginterprestasikan informasi yang diterimanya menjadi suatu gambaran yang berarti. Tidak hanya itu, Riadi (2012) menje-laskan bahwa persepsi tidak bertahan seumur hidup tapi dapat berubah sesuai dengan per-kembangan pengalaman, perubahan kebutuhan, dan sikap seseorang baik laki-laki maupun perempuan. Berkenaan dengan hal tersebut maka, seseorang dapat memiliki perubahan pandangan mengenai suatu objek sesuai dengan persepsinya. Adanya persepsi tersebutlah yang menentukan sikap, tingkah laku seseorang pada umumnya.

Vincent, Notoatmojo (dalam Jumiyati 2016: 10) mengemukakan banyak faktor yang menyebabkan stimulus masuk dalam rentang perhatian seseorang. Faktor tersebut terdiri dari dua bagian yaitu faktor internal dan faktor eksternal. Faktor internal adalah faktor yang terdapat pada orang yang mempersepsikan stimulus tersebut (Jumiyati, 2016: 10), sedangkan faktor eksternal adalah faktor yang melekat pada objek dan dipengaruhi oleh lingkungan sekitarnya. Faktor internal tersdiri dari a) pengalaman atau pengetahuan, b) harapan, c) kebutuhan, d) motivasi, e) emosi, dan f) budaya. Berbeda dengan faktor internal, faktor eksternal terdiri dari a) kontras, b) perubahan intensitas, c) pengulangan, d) sesuatu yang baru, e) sesuatu yang menjadi perhatian orang banyak.

Tidak hanya itu, adanya perubahan kurikulum pendidikan di
Indonesia merupakan suatu tantangan serta tuntuntan yang harus dilak ukan. Menurut Kurniasih (2016: 1-4) terdapat tiga aspek yang menjadi landasan pengembangan kurikulum secara jelas terangkum dalam isi materi uji kurikulum, yaitu: (1) landasan filosofis kurikulum 2013, (2) landasan yuridis dan empiris kurikulum 2013, dan (3) aspek konseptual. Landasan fisiologis kurikulum 2013 tertuang dalam UU No. 20 tahun 2003 tentang Sistem Pendidikan Nasional pada pasal 1 butir 1 yang berbunyi bahwa "Pendidikan adalah usaha sadar dan terencana untuk mewujudkan suasana belajar dan proses pembelajaran agar peserta didik secara aktif mengembangkan potensi dirinya untuk memiliki kekuatan spiritual keagamaan, pengendalian diri, kepribadian, kecerdasan, akhlak mulia, dan keterampilan yang diperlukan dirinya, masyarakat, bangsa, dan negara". Undang-undang tersebut dirumuskan berdasarkan pada dasar falsafah negara yaitu Pancasila.

Berkenaan dengan hal tersebut, maka kurikulum tidak semata-mata hanya menyoroti proses belajar saja, tetapi juga dikembangkan agar siswa memiliki kesempatan untuk berpartisipasi dalam mengembangkan nilai-nilai budaya dan nasional menjadi nilai budaya yang dapat digunakan dalam kehidupan sehari-hari. Sedikit berbeda dengan landasan fisiologis, pada landasan yuridis dan empiris Kurikulum 2013 juga tertuang dalam Permendikbud No. 65 tahun 2013 tentang Standar Proses Pendidikan Dasar dan Menengah menetapkan bahwa perencanaan pembelajaran dirancang dalam bentuk silabus dan Rencana Pelaksanaan Pembelajaran (RPP), penilaian proses pembelajaran menggunakan pendekatan penilaian otentik (authetic assesment) yang menilai kesiapan siswa, proses, dan hasil belajar secara utuh. Dalam pelaksanaannya, terdapat pula program remidial dan program pengayaan. 
Pelaksanasan kurikulum akan dapat berhasil jika guru dapat menyusun RPP, memahami konsep penilaian autentik dan melaksanakannya. Berkenaan dengan hal tersebut, dalam Permendikbud Nomor 71 Tahun 2003 juga menjelaskan mengenai buku teks pelajaran dan buku Panduan Guru untuk Pendidikan Dasar dan Menegah menetapkan Buku Teks Pelajaran sebagai buku siswa (lampiran I) dan Buku Panduan Guru sebagai buku guru (lampiran II) yang layak digunakan dalam pembelajaran. Berdasarkan aturan Permendikbud tersebut maka, hendaknya guru harus memahami dengan baik buku siswa maupun buku panduan guru. Tidak hanya itu, guru juga harus mampu menggunakan buku siswa maupun buku panduan guru dalam pembelajaran.

Berbeda dengan landasan fisiologis, landasan yuridis, dan empiris Kurikulum 2013, aspek konseptual dalam hal ini mencakup refrensi, model kurikulum, proses pembelajaran yang mencakup aktivitas belajar, output belajar dan outcome belajar serta cakupan mengenai penilaian. Bergantinya kurikulum ke arah yang lebih baik tentu saja tidak selalu berjalan mulus, selalu ada permasalahan. Namun, kurikulum yang sudah dicanangkan dan ditetapkan sudah berjalan. Sama halnya dengan penetapan Kurikulum 2013, seiring berjalannya waktu, permasalahan baru pun mulai bermunculan.

Berkenaan dengan hal tersebut, dalam pembelajaran bahasa Indonesia perlu adanya penekanan terhadap capaian kompetensi berba-hasa dan komunikasi. Seperti yang dikemukakan oleh Nurgiyantoro (2017: 304) menjelaskan bahwa cakupan pembelajaran bahasa meliputi, kompetensi bahasa (kompetensi linguistik), kompetensi berbahasa (kompetensi komuni $\neg$ katif), dan kompetensi bersastra.

Adanya perbedaan sifat dan kedu-dukan pembelajaran bahasa tersebut menuntut perbedaan tes bahasa bagi siswa pemelajar bahasa, khususnya berkenaan dengan tingkat kesukaran alat penilaian yang digunakan. Siswa Sekolah Menengah Akhir maupun Kejuruan (SMA/SMK) sudah dapat lebih menguasai bahasa Indonesia, sehingga alat penilaian yang diberikan pun sudah dapat mencakup bahan materi yang luas, kompleks, menyangkut masalah style atau bersifat apresiatif, dan mencakup fungsi komunikatif bahasa secara lebih meluas. Pembelajaran bahasa Indonesia di sekolah menengah akhir maupun kerjuruan meliputi pembelajaran mengenai bahasa yang berkaitan dengan kompetensi linguistik, kete-rampilan berbahasa yang berkaitan dengan tindak berbahasa (performance) atau berkenaan dengan fungsi komunikatif bahasa (kompetensi komu $\neg$ nikatif), dan kesusastraan.

Perlu diketahui bahwa ada 2 jenis keterampilan berbahasa yaitu keterampilan berbahasa produktif dan reseptif. Keterampilan berbahasa yang bersifat produktif meliputi, berbicara dan menulis. Keterampilan berbahasa yang bersifat reseptif meliputi, menyimak, dan membaca. Sebagaimana yang dikemukakan Tarigan (2015: 3) bahwa berbicara adalah suatu keterampilan berbahasa yang berkembang pada kehidupan anak, yang hanya didahului oleh keterampilan menyimak, dan pada masa tersebutlah kemampuan berbicara atau berujar dipelajari. Sejalan dengan pendapat tersebut, Iskandarwassid (2016: 241) mengemukakan bahwa keterampilan berbicara pada hakikatnya merupakan keterampilan mereproduksi arus sistem bunyi artikulasi untuk menyampaikan kehendak, kebutuhan perasaan, dan keinginan kepada orang lain. Tidak hanya itu, Nurgiyantoro (2017: 441) juga menjelaskan bahwa berbicara adalah aktivitas berbahasa kedua yang dilakukan manusia dalam kehidupan bahasa setelah mendengarkan. Berdasarkan beberapa pendapat tersebut, dapat diketahui bahwa 
berbicara merupakan kegiatan mengucapkan bunyi-bunyi bahasa yang memerlukan pelafalan, intonasi, struktur, dan kosa kata.

Menurut Tarigan (2015: 8) membaca adalah suatu kemampuan untuk melihat lambang-lambang tertulis serta mengubah lambang-lambang tertulis tersebut melalui fonik (phonics = suatu metode pengajaran membaca, ucapan, ejaan berdasarkan interpretasi fonetik terhadap ejaan biasa) menjadi/menuju membaca lisan (oral reading). Sebagaimana dikemukakan Tarigan (2013: 22) bahwa menulis ialah menurunkan atau melukiskan lambanglambang grafik yang menggambarkan suatu bahasa yang dipahami oleh seseorang, sehingga orang-orang lain dapat membaca lambang-lambang grafik tersebut kalau mereka memahami bahasa dan gambaran grafik itu. Sejalan dengan pendapat tersebut, Iskandarwassid (2016: 248) juga mengemukakan bahwa aktivitas menulis meru-pa $\neg$ kan suatu bentuk manifestasi kemampuan dan keterampilan berbahasa yang paling akhir dikuasai oleh pembelajar bahasa setelah ke-mampuan mendengarkan, berbicara, dan membaca. Berdasarkan beberapa pendapat tersebut, dapat diketahui bahwa menulis merupakan kegiatan menghasilkan bahasa yang berkenaan dengan struktur dan kosa kata secara tertulis.

\section{METODE}

Atikel ini ditulis berdasarkan penelitian dengan pendekatan maupun jenis penelitian berupa deskriptif kuantitatif. Menurut Margono (2014: 8) penelitian deskriptif berusaha memberikan dengan sistematis dan cermat fakta-fakta aktual dan sifat populasi tertentu. Tidak hanya itu, Sukmadinata (2017: 72) juga menjelaskan bahwa penelitian deskriptif dituju-kan untuk mendeskripsikan atau menggam-barkan fenomena-fenomena yang ada, baik fenomena yang bersifat alamiah ataupun rekayasa manusia. Selain itu, sukmadinata (2017: 53) juga mengemukakan kembali bahwa penelitian kuantitatif didasari oleh filsafat positivisme yang menekankan fenomena-fenomena objektif dan dikaji secara kuantitatif. Dalam penelitian deskriptif kuantitatif akan tergambar suatu kondisi yang sebenarnya, karena pada penelitian deskriptif kuantitatif tidak mengadakan manipulasi. Penelitian deskriptif kuantitatif juga dapat menggambarkan keadaan dalam beberapa tahapan atau aspek yang disoroti pada penelitian ini (penilaian afektif, penilaian kognitif, dan penilaian psikomotor dalam evaluasi pembelajaran keterampilan berbahasa produktif).

Populasi pada penelitian ini yaitu seluruh guru mata pelajaran bahasa Indonesia SMK Se-Kabupaten Banyumas. Penelitian ini hanya dilakukan terhadap sekelompok anggota sampel yang mewakili populasi. Adanya pembatasan populasi, maka penelitian hanya dilakukan terhadap sampel dalam populasi yaitu, guru mata pelajaran bahasa Indonesia SMK Se-Kabupaten Banyumas. Pengambilan sampel pada penelitian ini menggunakan purposive sampling (sampel bertujuan). Menurut Sugiyono (2016: 126) purposive sampling adalah teknik penentuan sampel dengan pertimbangan tertentu. Dikatakan tertentu dalam hal ini yakni adanya kriteria dan ciri yang dimiliki responden. Kriteria yang dimaksud yaitu guru bahasa Indonesia SMK se-Kabupaten Banyumas. Pemikiran tersebut sejalan dengan Sukmadinata (2017: 254) yang menjelaskan bahwa pengambilan sampel bertujuan disesuaikan dengan tujuan penelitian. Pada penelitian ini, sampel ditentukan sesuai dengan kebutuhan peneliti dikarenakan jumlah populasi pada penelitian ini adalah guru bahasa Indonesia SMK Se-Kabupaten Banyumas terbilang banyak yang tercatat di grup MGMP Bahasa Indoensia SMK CABDIN 
Wilayah X DISDIKBUD Provinsi Jawa Tengah.

Instrumen yang digunakan pada penelitian ini menggunakan lembar kuesioner (angket) dan tes. Pada penelitian ini, kuesioner atau angket dan tes online dipilih oleh peneliti sebagai instrumen penelitian. Pemilihan angket menggunakan sistem online dikarenakan, adanya KLB Corona atau Covid19 yang mengakibatkan semua sekolah harus mengadakan kegiatan belajar mengajar di rumah (daring atau jarak jauh). Berkenaan dengan situasi tersebut maka, peneliti memutuskan untuk melakukan penelitian kepada guru bahasa Indonesia SMK SeKabupaten Banyumas secara daring/jarak jauh menggunakan aplikasi google forms sebagai sarana pengisian kuesioner/angket dan tes online. Pengisian kuesioner/angket dan tes online melalui google forms dapat diakses melalui link yang sudah dipersiapkan oleh peneliti.

Pada penelitian ini menggunakan skala likert dan rating scale untuk mengumpulkan dan membantu menganalisis data. Skala likert digunakan untuk mengumpulkan data berupa persepsi, pendapat, maupun sikap dari suatu objek. Rating scale digunakan untuk mengum-pulkan data berupa kualitas yang dimiliki objek. Skala likert memiliki lima opsi atau pilihan jawaban. Dari 5 pilihan jawaban tersebut, selanjutnya akan diolah dalam bentuk persentase sebagai hasil penelitian. Sedikit berbeda dengan skala likert, rating scale memiliki komponen numerial rating scale. Numerial rating scale merupakan pernyataan mengenai kualitas tertentu dari objek yang diukur dan diikuti oleh angka yang menunjukkan kualitas objek itu sendiri.

Validitas pada penelitian ini menggu-nakan content validity (validitas isi). Validitas isi berkenaan dengan isi dan format dari instrumen (Sukmadinata, 2017: 229). Sejalan dengan Sukmadinata, Sugiyono (2016: 177) menjelaskan untuk menguji validas butir-butir instrumen lebih lanjut, maka setelah dikonsultasikan dengan ahli, maka selanjutnya diujicobakan, dan dianalisis dengan analisis item atau uji beda. Jadi pada validitas isi, instrumen dicek atau diteliti kembali apakah butir-butir yang ditanyakan sudah mewakili aspek-aspek yang akan diukur dan apakah penyusunan format instrumen sudah mewakili indikator pada kisi-kisi yang sudah dibuat. Pada penelitian ini, teknik pengumpulan data dilakukan dengan menggunakan kuesioner atau angket dan tes online melalui skala likert serta rating scale. Pengisian kuesioner/angket dan tes online melalui google forms dapat diakses melalui link yang sudah dipersiapkan oleh peneliti. Pada link yang sudah dipersiapkan peneliti, terdapat kuesioner mengenai persepsi dan pengetahuan guru bahasa Indonesia tentang evaluasi pembelajaran kete $\neg$ rampilan berbahasa produktif pada Kurikulum 2013 dalam bentuk kuesioner tertutup, kuesioner terbuka, dan tes.

Teknik analisis data yang digunakan dalam penelitian ini yaitu teknik analisis data statistik deskriptif melalui skala likert dan rating scale. Menurut Margono (2014: 190) analisis statistik deskriptif biasanya dipergunakan kalau tujuan penelitiannya untuk penjajagan atau pendahuluan, tidak menarik kesimpulan, hanya memberikan gambaran/deskripsi tentang data yang ada. Jadi, teknik analisis statistik deskriptif digunakan untuk mendeskripsikan atau meng-gambarkan data yang telah terkumpul seba-gaimana adanya. Selain itu, skala likert dipilih karena digunakan untuk membantu menganalis data berupa pendapat, persepsi, maupun sikap seseorang terhadap suatu objek. Rating scale digunakan untuk membantu menganalisis data yang berisikan perangkat pernyataan kualitas sesuatu yang akan diukur. Tidak hanya itu rating scale juga digunakan untuk membantu menganalisis dalam hal menilai objek 
yang menunjukkan peringkat kualitas yang dimiliki.

\section{HASIL DAN PEMBAHASAN}

Sebagaimana diketahui pembelajaran keterampilan berbahasa produktif akan dapat berjalan sepenuhnya, apabila dilaksanakan sesuai dengan prosedur pelaksanaan yang baik. Prosedur pelaksanaan yang baik berupa langkahlangkah yang perlu diikuti apabila melaksanakan penilaian hasil belajar atau evaluasi pembelajaran. Adapun komponen evaluasi pembelajaran yang berupa: penentuan spesifikasi penilaian, pengu $\neg$ jian instrumen atau alat penilaian, pelaksanaan penilaian, penafsiran hasil penilaian, aspek evaluasi pembelajaran keterampilan berbahasa produktif, dan tes keterampilan berbahasa produktif. Evaluasi pembelajaran merupakan suatu proses untuk menentukan nilai dari hasil pembelajaran. Berkenaan dengan hal tersebut, untuk mewujudkan kegiatan evaluasi diperlukan intrumen tertentu, diantaranya adalah tes.

Sebagaimana diketahui, penyelenggaraan pembelajaran bahasa Indonesia memerlukan adanya kompetensi guru. Salah satu kompetensi yang wajib dikuasai guru adalah kemampuan melaksanakan evaluasi pembelajaran maupun penilaian proses dan hasil belajar bahasa Indonesia. Pentingnya pengusaan guru dalam melaksanakan evaluasi pembelajaran baik penilaian hasil belajar siswa, agar dapat diketahui sejauh mana keberhasilan pembelajaran, ke $\neg$ mampuan siswa, serta untuk menentukan langkah-langkah yang perlu dilakukan pada pembelajaran selanjutnya. Evaluasi pembelajaran bahasa memiliki sistematika atau pola yang hampir sama dengan model evaluasi dalam ilmu sosial lainnya. Langkahlangkah evaluasi pembelajaran dilakukan mulai dari tahapan persiapan, pelaksanaan, pengolahan hasil tes, dan tindak lanjut. Namun, evaluasi pembelajaran bahasa maupun ilmu sosial lainnya memiliki perbedaan yang terletak pada pendalaman butir soal yang disesuaikan dengan tujuan evaluasi.

Permasalahan yang ada pada evaluasi pembelajaran bahasa terbilang cukup kompleks karena, melibatkan berbagai kriteria penilaian yang memiliki bobot beragam. Namun, bobot yang beragam tersebut masih memiliki kedekatan skor sehingga memerlukan kajian yang mendalam dan seksama dalam penyusunan kisi-kisinya. Pada evaluasi pembelajaran bahasa Indonesia juga memiliki pola yang sama, penilaian kosakata, gaya bahasa, tata bahasa, dan lain-lain juga memerlukan bobot yang argu-mentatif. Berkenaan dengan hal tersebut, peneliti mendapati adanya pemahaman guru mengenai evaluasi pembelajaran keterampilan berbahasa produktif.

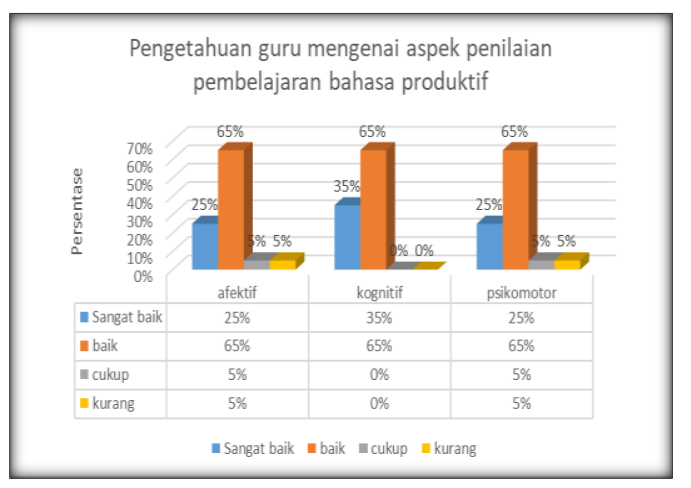

Gambar 1 Pengetahuan guru mengenai aspek penilaian pembelajaran bahasa produktif

Dalam kegiatan pembelajaran, guru merupakan suatu komponen yang penting dalam penyelenggaraan pendidikan. Guru sebagai tenaga kependidikan merupakan seseorang yang bertugas untuk mengelola kegiatan pembelajaran yang lebih efektif. Maka itu, diperlukan adanya studi lanjut mengenai persepsi maupun pe $\neg$ ngetahuan guru bahasa Indonesia terhadap evaᄀluasi pembelajaran pada keterampilan berbahasa produktif. Seperti yang sudah 
dijelaskan pada bab sebelumnya, persepsi merupakan proses pe $\neg$ nilaian seseorang terhadap objek tertentu. Melalui proses tersebut, akan diperoleh suatu tanggapan dari apa yang sudah menjadi persepsi selama ini.

Berkenaan dengan tingginya persepsi atau anggapan bahwa guru dapat menguji keteram $\neg$ pilan berbahasa produktif dalam pembelajaran bahasa Indonesia, ternyata tidak sebanding dengan tingkat persentase kesulitan yang dialami guru dalam evaluasi pembelajaran maupun penilaian hasil belajar bahasa Indonesia. Berikut ini diagram batang mengenai persentase persepsi kesulitan guru terhadap aspek penilaian pembe $\neg$ lajaran keterampilan berbahasa produktif.

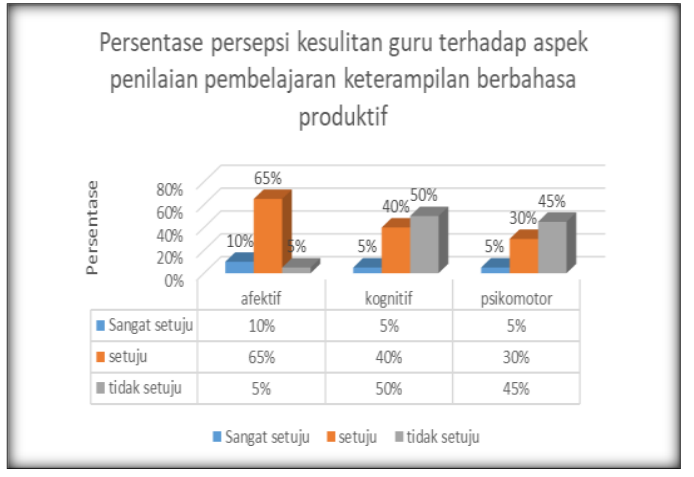

Gambar 2 Persentase persepsi kesulitan guru terhadap aspek penilaian pembelajaran keterampilan berbahasa produktif

Berdasarkan gambar diagram batang tersebut, menunjukkan bahwa masih ada seba-gian guru yang memiliki kesulitan pada setiap aspek penilaian pembelajaran keterampilan berbahasa produktif. Sebagaimana diketahui aspek penilaian pembelajaran meliputi aspek penilaian afektif (sikap), aspek penilaian kognitif (pengetahuan), dan aspek penilaian psikomotor (keterampilan). Sebagaimana diketahui pengeta $\neg$ huan merupakan domain yang sangat penting untuk terbentuknya tindakan seseorang (ovent behavior). Pengetahuan akan muncul ketika seseorang menggunakan pikirannya untuk mengenali benda atau kejadian tertentu yang belum pernah dilihat atau dirasakan sebelumnya. Berkenaan dengan hal tersebut, adanya penge $\neg$ tahuan guru terhadap evaluasi pembelajaran juga penting untuk menunjang terlaksananya kegiatan pembelajaran. Tidak hanya persepsi, dengan mengetahui bagaimana pengetahuan guru mengenai evaluasi pembelajaran keterampilan berbahasa produktif juga diharapkan dapat diketahui pula langkah-langkah serta kiat-kiat dalam melaksanakan evaluasi pembelajaran tersebut. Tidak hanya sekedar berbekal penge $\neg$ tahuan mengenai evaluasi saja tetapi, guru bahasa Indonesia juga hendaknya memiliki kemampuan yang cukup dalam menilai jalannya proses evaluasi pembelajaran maupun penilaian kete $\neg$ rampilan berbahasa.

Dalam hal ini, semata-mata tidak hanya mempertimbangkan penilaiannya saja me-lainkan juga dilakukan untuk menentukan keberhasilan proses pembelajaran serta untuk memeriksa keberlancaran, kendala, serta kualitas proses pembelajaran tersebut. Evaluasi yang dilakukan oleh guru pun hendaknya relevan dengan karakteristik bahan pembelajaran serta keterampilan yang sedang diukur. Hal yang umum dilakukan guru pada saat akan melakukan penilaian hasil belajar ialah menetapkan tujuan serta sistem penilaian yang akan disusun dan dipergunakan.

Sebagaimana diketahui, persepsi meru-pakan suatu tanggapan yang muncul melalui proses penilaian seseorang terhadap objek tertentu. Tidak hanya itu, persepsi juga dianggap sebagai proses bagaimana seseorang menyeleksi, mengatur, maupun menginterpretasikan segala informasi yang diterima. Berkenaan dengan hal tersebut, adanya persepsi guru terhadap suatu evaluasi pembelajaran juga penting untuk menunjang terlaksananya kegiatan pembe $\neg$ lajaran. Dengan mengetahui 
bagaimana persepsi guru dalam melaksanakan evaluasi pembe $\neg$ lajaran, diharapkan dapat diketahui pula langkahlangkah, kiat-kiat, serta kendala yang dihadapi oleh guru dalam melaksanakan evaluasi pem-belajaran keterampilan berbahasa produktif dalam Kurikulum 2013 di tingkat SMK (Sekolah Menengah Kejuruan).

Persepsi mengenai evaluasi pembelajaran juga akan berkaitan dengan pemahaman dan pemaknaan guru bahasa Indonesia terhadap evaluasi pembelajaran keterampilan berbahasa produktif itu sendiri. Dari persepsi tersebut, guru bahasa Indonesia dapat melakukan evaluasi pembelajaran sesuai dengan pemahaman dan pemaknaan mengenai pembelajaran keteram $\neg$ pilan berbahasa produktif.

\section{KESIMPULAN}

Berdasarkan pembahasan hasil penelitian diketahui bahwa 79,2\% guru dapat melak $\neg$ sanakan dan memahami evaluasi pembelajaran keterampilan berbicara, serta diketahui pula 86,3\% guru dapat melaksanakan dan memahami evaluasi pembelajaran keterampilan menulis. Tidak hanya itu, hampir semua guru juga beranggapan dapat menguji keterampilan berbicara maupun keterampilan menulis siswa dalam pembelajaran bahasa Indonesia. Berke $\neg$ naan dengan perolehan tersebut, ternyata tidak sebanding dengan perolehan tingkat persentase kesulitan yang dialami guru dalam evaluasi pembelajaran maupun penilaian hasil belajar bahasa Indonesia. Ada sebagian guru yang memiliki kesulitan pada setiap aspek penilaian pembelajaran keterampilan berbahasa produktif.

Hal tersebut dibuktikan dengan adanya perolehan persentase pada butir angket nomor 34 sebesar $10 \%$ 'sangat setuju', 65\% 'setuju', 10\% 'ragu-ragu', 5\% 'tidak setuju', dan 10\% 'sangat tidak setuju' bahwa evaluasi yang sulit dilakukan pada penilaian keterampilan berbahasa produkti adalah aspek penilaian afektif (sikap). Berbeda dengan penilaian afektif (sikap), pada penilaian kognitif (pengetahuan) ternyata sebagian guru memiliki anggapan bahwa penilaian kognitif (pengetahuan) tidak sulit dilakukan pada keterampilan berbahasa produktif.

Persepsi atau anggapan tersebut dibuktikan dengan adanya perolehan persentase pada butir angket nomor 36 sebesar 5\% 'sangat setuju', 40\% 'setuju', $5 \%$ 'ragu-ragu', dan 50\% 'tidak setuju' bahwa penilaian kognitif sulit dilakukan. Sama halnya dengan penilaian kognitif (pengetahuan), penilaian psikomotor (pengetahuan) juga dianggap oleh sebagian responden tidak sulit untuk dilakukan pada penilaian keterampilan berbahasa produktif. Hal tersebut dibuktikan dengan adanya perolehan persentase pada butir angket no 38 sebesar $5 \%$ 'sangat setuju', 30\% 'setuju', 15\% 'ragu-ragu', 45\% 'tidak setuju' dan 5\% 'sangat tidak setuju' bahwa penilaian psikomotor (pengetahuan) sulit dilakukan. Berkenaan dengan hal tersebut, maka diketahui bahwa penilaian afektif (sikap) lebih cenderung sulit untuk dilakukan dalam evaluasi pembelajaran keterampilan berbahasa produktif pada pembelajaran bahasa Indonesia.

Tidak hanya itu, ditemukan pula bahwa hampir semua guru sudah dapat memahami dan dapat membedakan aspek penilaian afektif (sikap), penilaian kognitif (pengetahuan), dan penilaian psikomotor (keterampilan) dalam evaluasi pembelajaran keterampilan berbahasa produktif. Hal tersebut dibuktikan dengan adanya perolehan persentase pada butir angket nomor 33 sebesar $25 \%$ 'sangat setuju', 65\% 'setuju', 5\% 'ragu-ragu', dan $5 \%$ 'tidak setuju' bahwa guru hendaknya dapat memahami dan membedakan penilaian afektif dalam evaluasi pembelajaran keterampilan berbahasa produktif. Berbeda dengan penilaian 
afektif (sikap), pada penilaian kognitif (pengetahuan) responden menampilkan respon yang baik. Hal tersebut dibuktikan dengan adanya perolehan persentase pada butir angket nomor 35 sebesar 35\% 'sangat setuju' dan $65 \%$ 'setuju'. Adanya perolehan persentase tersebut, juga memperlihatkan bahwa tidak ada responden yang merasa kesulitan untuk memahami dan membedakan penilaian kognitif (pengetahuan) dalam evaluasi pembelajaran keterampilan berbahasa produktif.

Pada penilaian psikomotor (keterampilan) responden juga masih menampilkan respon yang baik. Hal tersebut dibuktikan dengan adanya perolehan persentase sebesar $25 \%$ 'sangat setuju', 65\% 'setuju', 5\% 'ragu-ragu', dan $5 \%$ 'tidak setuju' bahwa guru dapat memahami penilaian psikomotor (keteranpilan). Adanya perolehan persentase tersebut, memperlihatkan bahwa banyak responden yang tidak mersa kesulitan dalam memahami dan membedakan penilaian psikomotor (keterampilan) dalam evaluasi pembelajaran pada setiap keterampilan berba-hasa.

\section{DAFTAR PUSTAKA}

Arikunto, Suharsimi. 2010. Dasar-dasar Eva-luasi Pendidikan (Edisi Revisi). Jakarta: Bumi Aksara.

Iskandarwassid, dan H Dadang Sunendar. 2016. Strategi Pembelajaran Bahasa. Bandung: Rosdakarya.

Jumiyati. 2016. Persepsi dan Pengetahuan Guru Terhadap Evaluasi Pembelajaran Bahasa Indonesia Kelas VI dalam KTSP Di UPTD Karangreja Kabupaten Purbalingga. Pur $\neg$ wokerto: UMP.

Kementerian Pendidikan Kebudayaan. 2016. Silabus Mata Pelajaran
(SMA/MA/SMK/ MAK) Mata Pelajaran Bahasa Indonesia. Jakarta: Kemendikbud.

Kurniasih, Imas dan Berlin Sani. 2016. Revisi Kurikulum 2013 Implementasi Konsep dan Penerapan. Sumatera Barat: Kata Pena.

Margono, S. 2014. Metodologi Penelitian Pendiᄀdikan. Jakarta: Rineka Cipta.

Nugraha, Ugi. 2015. Hubungan Persepsi, sikap, dan Motivasi Belajar Terhadap Hasil Belajar pada Mahasiswa Pendidikan Olah-raga dan Kesehatan Universitas Jambi Edisi 1 No 1 Maret. Jambi: Universitas Jambi (Jurnal Cerdas Sifa). https://online-journal. unja.ac.id.

Nurgiyantoro, Burhan. 2013. Penilaian Pembe-lajaran Bahasa Berbasis Kompetensi. Yogyakarta: BPFE.

2015. Penilaian Otentik dalam Pem-belajaran Bahasa. Yogyakarta: Gadjah Mada University Press.

Nurgiyantoro, Burhan. 2017. Penilaian Pembe-lajaran Bahasa Berbasis Kompetensi Edisi Kedua. Yogyakarta: BPEE.

Riadi, 2012. Teori Persepsi. http://www.kajianpustaka.com/20 12/10/teori-pengertian-prosesfaktor-persepsi.html. Diunduh pada tanggal 4 september 2019.

Sugiyono. 2016. Metode Penelitian Kombinasi (Mixed Methods). Bandung: Alfabeta. 
Sukmadinata, Nana Syaodih. 2017. Metode Penelitian Pendidikan. Bandung: Remaja Rosdakarya Offset.

Tarigan, Henry Guntur. 2013. Menulis Sebagai Suatu Keterampilan Berbahasa. Bandung: CV. Angkasa.

2015. Berbicara Sebagai Suatu Keterampilan Berbahasa. Bandung: CV. Angkasa

Wawan. A, dan Dewi M. 2010. Teori dan Pengukuran Pengetahuan, Sikap, dan Perilaku Manusia Dilengkapi Contoh Kuesioner. Yogyakarta Nuha Medika. 